\title{
Obraz města v románech dvou spisovatelek slovanského původu: Praha Daniely Hodrové a Bělehrad Svetlany Velmarové-Jankovićové
}

Ivana Kočevski (Bělehrad)

\begin{abstract}
Abstrakt
Příspěvěk se zabývá možností porovnání poetiky dvou spisovatelek - Daniely Hodrové a Svetlany Velmarové-Jankovićové. Literární dílo české i srbské spisovatelky je založeno převážně na zobrazování prostoru rodného města, přičemž jejich výrazové prostředky nesou jistou podobnost - prolínání subjektivních vzpomínek s kolektivní historií. Styčné plochy mezi oběma spisovatelkami můžeme vidět v jejich zájmu o budovy, památníky či rưzné kulturní památky určitého města. Obě literátky reflektuji své rodné město, což lze vyčíst z jejich prózy. Komparaci literárních témat a poetiky obou autorek Ize demonstrovat na trilogii Hodrové, symbolicky nazvané Trýznivé město (jež obsahuje romány Podobojí, Kukly, Théta), doplněné esejistickou prózou Město vidím, u Svetlany Velmarové-Jankovićové se jedná o díla Dorćol, Vračar a román Lagum (Žalár).
\end{abstract}

\section{Klíčová slova}

Daniela Hodrová; Svetlana Velmarová-Jankovićová; město; dějiny; Praha; Bělehrad

\begin{abstract}
The Image of the City in the Novels of Two Writers of Slavic Origin: Prague by Daniela Hodrová and Belgrade by Svetlana Velmar-Janković

The study analyzes the possibility of comparing the poetics of two writers - Daniela Hodrová and Svetlana VelmarJanković. The literary work of Czech and Serbian writer is mainly based on presenting the space of their hometown which they both do in a similar manner - by interweaving their personal memories with collective history. Contact points between the two authors are to be seen in their interest in buildings, monuments and other cultural city sights. Both writers reflect their hometown in themselves which could be read in their prose. The comparison of their interests and poetics could be conducted on Hodrová's trilogy symbolically named as The Tormented city (which contains the novels The Kingdom of Souls, Cocoons and Theta), supplemented with the book of essays I see the city, and Velmar-Janković's documentary prose Dorćol, Vračar and novel The Dungeon.
\end{abstract}

\section{Key words}

Daniela Hodrová; Svetlana Velmar-Janković; city; history; Prague; Belgrade

Tato studie vznikla v rámci grantového projektu ON-178003 Književnost i vizuelne umetnosti: rusko-srpski dijalog za podpory Ministarstva prosvete, nauke i tehnološkog razvoja Republike Srbije. 
V dílech některých spisovatelů 20. století se topos města stává paradigmatem formování poetiky a významovou výstavbou literárního díla, přičemž prostor urbánního prostředí není využit pouze jako kulisa románového dění, nýbrž občas se město samo stává hlavním hrdinou románu. Obraz města potom nemusí být nutně podrobený mimetickému napodobování existující skutečnosti, ale především může být východiskem diegetického modelování možného světa. Mnohonásobná inspirace rodným městem je viditelná v próze dvou literátek slovanské provenience - české a srbské literatury, v jejichž díle nalezneme hodně podobných vlastností. Jedná se o Danielu Hodrovou (1946) a Svetlanu Velmarovou-Jankovićovou (1933-2014), jež často věnují pozornost Praze, resp. Bělehradu, městům, která se následně stávají svérázným tématem jejich próz. Komparaci literárních témat a poetiky obou autorek je možné demonstrovat na trilogii Hodrové, symbolicky nazvané Trýznivé město, doplněné esejistickou prózou Město vidím, u Svetlany Velmarové-Jankovićové se jedná o díla Dorćol, Vračar a román Lagum (Žalář).

Dvě evropská města, navzájem vzdálená asi tisíc kilometrů, jsou už po staletí centrem kultury a civilizace, kořistí v očích dobyvatelů, rozcestníkem historických událostí, přesto však odlišného osudu i původu. Zdá se ovšem, že kromě svých určitých zvláštností, které je rozdělují, lze pro ně nalézt společné prvky v zajímavé konstataci Vladislavy Gordićové Petkovićové, která říká: „Evropská města představuji slib svobody, možnost objeveni tradice podněcujici rozvoj osobnosti namisto podrobeni ji určitým vzorìm, lákavou šanci dospiváni a afirmace - až do chvile zániku schopností rozvoje a dospíváni v ohromujicím poznání, že se jednalo jenom o šikovně vyrobenou manipulaci. Mèsto se tedy stává bud’ hřbitovem iluzi o životě a lidech, nebo žaläřm, do kterého naivni hrdina dobrovolně vstoupil, nevědomý, co si čini. “1

Kromě své, dovolila bych si říct, majestátní literární tvorby je Hodrová autorkou stejně důležitých a originálních teoretických prací, ve kterých je představování prostoru (mimo jiné) velice častým tématem (Mista s tajemstvím. Kapitoly z literárni topologie, 1994; Poetika mist, 1997; Citlivé město. Eseje z mytopoetiky, 2006). Ačkoliv pro Hodrovou jsou klíčové autentické literární předlohy, které v dílech současných srbských spisovatelů nenajdeme (myslíme především narativní koncept „archipsaní-tkaní“), je oběma autorkám společný vynikající způsob čtení městského textu, u Hodrové zasvěcenost Praze, stejně tak u Svetlany Velmarové-Jankovićové, o něco starší srbské literátky, zasvěcenost Bělehradu.

Svetlana Velmarová-Jankovićová se zapsala do dějin srbské literatury jak svou beletristickou tvorbou, působením v literárním nakladatelství, nespočetnými odbornými statěmi, tak i svým členstvím v Srbské akademii věd a umění. Na rozdíl od Hodrové se nezajímala o teorii románu jako o literární druh, teorii prostoru nebo literární topografii. Avšak její láska $\mathrm{k}$ rodnému městu a zasvěcené bádání o jeho historii a kultuře ji přivedla k sepsání monumentální monografie s názvem Brána Balkánu (Kapija Balkana, 2011), s podtitulem Rychlý pri̊vodce dějinami Bèlehradu. Právě v uvedeném podtitulu objevujeme způsob, který spisovatelka použila v představení prostoru města - prostřednictvím jeho historie. V jednom rozhovoru srbská literátka vysvětlila, že pro ni jsou „dějiny důležitým základem vyprávění. Nad dějinami sprádáme a tkáme všschno, co setrvává jako podstata v daném času vyprávèni. Zdá se nám snadné postavit sebe jako subjekt do dějin, ale je to současnĕ

1 GORDIĆ-PETKOVIĆ, Vladislava: Urbana topografija u američoj $i$ srpskoj prozi: egzil $i$ heterotopija. In: ČUBROVIĆ, B. (ed.): Grad u jeziku, književnosti i kulturi. Beograd: Philologia, 2005, s. 68. 
velmi těžké, nebot' základ dějin, který se nám jevi jako spolehlivý, najednou se zdá také vratký. Jako by se vlnil v určitých obdobich, a dovoli vám ho chápat rozlišnými způsoby. "2

Pro Danielu Hodrovu souvisí vnímání města neustále jak se subjektivním čtením jeho dějin vrytých do jeho ulic, fasád, střech, interiérů, tak s osobní reminiscencí na místa, která někdy navštívila a která pro ni mají zvláštní význam. Toto lze zejména odhalit v knize Město vidím, ve které se soukromé dějiny spisovatelky mísí s dějinami rodného města. V prologu této esejistické prózy Hodrová vypráví, že na počátku pro ni byla Praha jen slovem, za kterým následovalo kouzlo bytí města. Takovýto počátek budování narativu připomíná starozákonní počátek, kde z jednoho slova vzniká celý svět. Podobně také v případě Prahy se u Hodrové následně vyvalí mikrouniverzum pestrosti. V její alegorické představě města je Praha číhající šelma, která čeká, aby ji někdo objevil.

Dějinami chce Svetlana Velmarová-Jankovićová vlastně představit osud člověka v určitém čase jeho bytí; svoji esejisticko-beletristickou prózu Dorćol a Vračar tak splétá pomocí osudů jednotlivců, kteří se zapsali jak do národních dějin, tak do dějin Bělehradu. Líčením existujících ulic v současném Bělehradě, ohraničených městskou částí Dorćol (z tureckého Dort-jol, znamenající rozcestí čtyř cest), se spisovatelka soustřed'uje na část národních dějin, které poznamenaly osobnosti, jejichž jména tyto ulice nesou. Velmarová-Jankovićová vdechuje život prostoru starého města vypravováním legend a pověstí zachovaných jak v kolektivní paměti, tak v pramenech o osobnostech 19. století. Ulice nicméně postupem času měnily svou podobu a majitele - mnohé budovy byly zbourány a zničeny a na jejich místě vystavěny nové domy a budovy s novým účelem a jmény, nepřetržitým změnám byla vystavena i jména ulic. Může to být náhoda, může to být i záměr, ale většina ulic současného Dorćolu je pojmenována podle významných Srbů, jejichž dílo zanechalo v politickém a kulturním životě Bělehradu během 19. století trvalou stopu.

Próza Svetlany Velmarové-Jankovićové se skládá ze čtrnácti povídek, které se z hlediska určení literárního žánru pohybují na hranici mezi esejistickou reflexí a povídkami, ve kterých se historické osobnosti, zastoupené staviteli, kupci, překladateli, měštany a vzdělanci, stávají součástí autorské fikce. Předmětem spisovatelčina zájmu tak není jenom prostor města jako základ představení historických událostí a změn, nýbrž i zobrazení osobností, jako byli např. bratři srbského knížete Miloše Obrenoviće ${ }^{3}$ - Jevrem a Jovan, nebo ctěné osobnosti srbské společnosti - Dositej Obradović4 ${ }^{4}$ Miša Anastasijević, Sima

2 JEREMIĆ, Zoran: Istorija i pripovedanje. In: PANTIĆ, M. (ed.): Bezdane svetlosti. O književnom delu Svetlane Velmar-Janković. Beograd: Biblioteka grada Beograda, 2012, s. 5-6.

3 Miloš Obrenović I. (1780-1860) byl v letech 1815-1839 a 1858-1860 srbským knížetem a zakladatelem panovnické rodiny Obrenovićů. Jako mladý se účastnil prvního srbského povstání (1804) a vedl druhé srbské povstání (1815). Jeho úspěch v boji proti turecké nadvládě vyústil jednání s Turky, ve kterých Osmanská ř́ře přiznala Srbsku autonomní statut a Milošovi postavení knížete. Přes to dosáhl Miloš i dalších úspěchů. Obdržel nejen berat, kterým potvrzen byl jako kníže, ale r. 1833 i hattišerif, kterým vyřízena byla záležitost státních hranic. Miloš zahájil proces modernizace a rozvoje Srbska. Cílem tohoto procesu však nebylo zemi dotáhnout na úroveň západních monarchií, nýbrž zajistit dostatečný počet vzdělaných lidí, kteří by dokázali spravovat stát. Podporoval proto studium některých studentů v zahraničí (Německu, Rakousku a Rusku) a také příchod zahraničních odborníkủ. Miloš nejdřív sídlil a panoval v Kragujevaci, který se stal hlavním městěm Srbska r. 1817. Po zasedání Státní rady r. 1839 se stal hlavním městem Bělehrad, kam se poté Miloš přesidlil.

4 Každá z osobností uvedených na tomto místě svou veřejnou, kulturní a politickou činnosti přispěla 
Nešić, Jovan Dobrača, Vasa Čarapić, Uzun Mirko Apostolović, Stojan Čupić a jiní. V líčení prostoru města je u Velmarové-Jankovićové, ostatně stejně jako u Daniely Hodrové, přítomný jistý anachronismus, jelikož se zde navzájem setkávají lidé z rozličných století. Jakkoli se jedná o osobnosti již dávno zesnulé, jejich duch odmítá opustit město a chodí jeho ulicemi, kde stál kdysi jejich dům.

Kniha Dorćol (1981) není dokumentární prózou, přestože autorka jasně použila psané prameny o Bělehradě a zmíněných osobnostech (částečně uváděla zdroje v poznámkách pod čarou), nýbrž postavy zobrazila dle vlastních dojmů a přesvědčení, a částečně na základě svědectví, která získala z ústního vyprávění a jiných zdrojů. Podobný moment nacházíme u Hodrové v trilogii Trýznivé město. Svetlana Velmarová-Jankovićová jim připisuje určitou povahu, když popisuje jejich bázně, nejistoty, podezření, přání, oběti, rozhodnutí, ke kterým dospěli, nebo vášně a pokání, které cítili. Svými politickými ambicemi a kulturním povědomím každá z uvedených osobností spoluutvářela nejenom vzhled ulic a účel některých budov, ale i kolektivní osud srbského národa (podobný postup použila Hodrová v románu Podobojî).

Koncept narativní výstavby z knihy Dorćol použila spisovatelka také v próze Vračar (1994), kterou doplnila ve vydání z roku 2005. Tuto napůl dokumentární a napůl fiktivní prózu začala psát odvolávajíc se na pověsti o srbském vládci Stefanu Lazarevićovi ${ }^{5}$, za jehož života se stal začátkem 15. století Bělehrad poprvé srbským hlavním městem - srbský panovník dostal toto město od uherského krále Zikmunda. Podle pověsti měl srbský despota někdy mezi lety 1422 a 1423 jakési nadpřirozené vidění na místě, kde se dnes nachází obec Vračar, a tak se rozhodl vybudovat právě na tomto místě kostel svatého Mikuláše (jenž byl dokončen roku 1425). Od té doby podle různých svědectví se toto místo stalo dějištěm dalších nadpřirozených jevů a zvláštních úkazů. Svetlana Velmarová-Jankovićová se v souvislosti s tímto místem zmiňuje o nadpřirozených silách, jimiž

k osvobození a založení srbského státu v 19. století. Pro ilustraci přiblí̌íme jenom Dositeje Obradoviće, abychom př́liš neodbočili od hlavního textu. Dositej Obradović (1742-1811) byl srbský osvícenec, reformátor, encyklopedista, kazatel a spisovatel. V mládí vstoupil do kláštera, kde studoval a měl se stát mnichem. Na podzim r. 1782 se vydal přes Lvov a Vratislav na universitu do Halle, kde - svléknuv mnišské roucho - studoval estetiku, filozofii a naturální teologii. Zatoužil otisknout své spisy v národním jazyce, a proto př̌šel na univerzitu do Lipska, kde fungovala „slovanská“ tiskárna. Obradović se stal spisovatelem tím, že jako první tiskl své práce jazykem téměř národním a to v době, kdy knihy ruské a staroslovanské nabývaly takového vlivu, že nejen udusily veškeré pokusy psát v národním jazyce, ale měly zvrátit veškerý vývoj srbské literatury, poněvadž se nejen neohlížely na tzv. srbskou redakci staroslovanštiny, nýbrž uváděly staroslovanštinu ruské výslovnosti podle naprosto nesprávných mluvnic. Obradović napsal mnohé spisy v duchu osvíceneckých tradic, které měly podpořit vznik srbského národního programu a celonárodní konsolidace.

5 Stefan Lazarević (1377-1427) byl synem knížete Lazara Hrebeljanoviće a s tituly knížete, (1389-1402) a despoty (1402-1427) vládl v Srbsku. Po otcově smrti v bitvě na Kosově poli roku 1389 přišel jako nezletilý do vlasti a s pomocí své matky Milice Nemanjić vládl do plnoletosti v roce 1393. Jako turecký vazal byl ročně povinen choditi k Portě a účastnit se vojensky tureckých tažení. Stefan byl v tureckém vojsku také v bitvách u Nikopole r. 1396 proti králi Zigmundovi a u Angory r. 1402 proti Timurovi. Timurovo vítězství jej zbavilo turecké vrchnosti. Již r. 1403 se stal uherským vazalem, obdržel od krále Zigmunda doživotně Bělehrad a Mačvu a k tomu i četné statky v Uhrách. Vlastnil velkou knihovnu, v níž shromáždil řadu prací o filozofii, historii a poezii ve slovanských jazycích, ale i v řečtině a latině. Založil několik klášterů, z nichž nejznámější je klášter Manasija. Je považován za jednoho z největších srbských vladařů a vojevůdců vůbec. Jeho literární díla ho řadí mezi nejlepší srbské spisovatele středověku. 
je vysvětlována mysteriózní smrt Jana Hunyadiho ${ }^{6}$, správce Uher a známého turkobijce, nedlouho poté, co právě na Vračaru porazil Turky (1456). Spisovatelka se pak zmiňuje o dalších neobvyklých a podivných rozumem těžce vysvětlitelných událostech jež měly souvislost s ustavičnými bitvami a válkami, které se v Bělehradě bud' odehrály, nebo byly o Bělehrad svedeny. Mimo jiné uvádí případ spálení ostatků největšího srbského světce, svatého Sávy ${ }^{7}$, což Turci provedli právě na Vračaru roku 1594, aby se pomstili vzdornému srbskému lidu. Hned poté vysvětluje, že podle legendy všichni, kteří se zúčastnili nebo přímo spáchali tento neslýchaný čin, brzy rovněž zemřeli mysteriózní smrtí. Zmíněnou záhadu autorka vztahuje k významu jména Vračar: „Velmi starý a slovanský název - Vračar - se poprvé objevuje $v$ rakouských dokumentech z dvacátých let 15 . století a potom začátkem čtyricátých let, turecké dokumenty jej zaznamenávaji teprve v osmdesátých letech téhož století a stále vice v souvislosti s válčenim. V ústním podáni, jež je starobylejši než kterýkoliv dokument, a tak možná spolehlivější, se Vračar zachoval jako misto věšěni, čarováni a kouzel, na kterém po mocných vzájemných zápasech síly dobra vítězi nad silami zla, tak jak světlo přemáhá temnotu."8

Prózu Vračar (1989) Svetlana Velmarová-Jankovićová doplnila během roku 2004 životopisem o Petru Nikolajeviči Moleru9. Jedna z ulic v bělehradské čtvrti Vračar je totiž pojmenovaná podle Molera, což přivedlo spisovatelku k tomu, aby použila stejný postup výstavby narativu jako v příkladu prózy Dorćol a zobrazila tuto městskou část povídáním příběhem o historické osobnosti, jejíž duch stále ještě žije v současném městě. Tímto životopisem autorka znázornila dějiny a osud srbského lidu koncem 18. a začátkem 19. století. Název Molerovy ulice v této próze má podobu odkazu jako elektronický internetový záznam. Název ulice není jenom určitá lokace v prostoru města, nýbrž heslem konkrétního času a se spoustou údajů o společensko-historickém a kulturním dění srbské země a jejího lidu. Název ulice je okno do světa, okno do minulosti, spona mezi tím, co jsme zapomněli a nadějí, že budeme pamatovat lidi, po kterých byla pojmenována.

6 János Hunyadi v dobových pramenech nazývaný také Turkobijec nebo Bílý rytír, (zemřel r. 1456 v Zemunu u Bělehradu) byl sedmihradský šlechtic, vojevůdce a jedna z významných osobností 15. století. Získal od krále Vladislava I. (Uherského a Polského) tituly sedmihradského vévody, temešského správce a hlavního kapitána Bělehradu. Dokázal jako jeden z mála velitelů své doby úspěšně čelit osmanským Turkům. Sultán Mehmed II. se rozhodl dobýt co nejdřív Bělehrad, který považoval za klíč k Uhrám. V červenci 1456 Hunyadi sice Bělehrad před Turky ubránil, vzápětí však zemřel na mor, který se rozšířil ve vojenském táboře.

7 Svatý Sáva (okolo 1175-1235/1236), byl nejmladší syn velkého rašského župana Štěpána Nemanji, jménem Rastko, stal se prvním srbským arcibiskupem (1219-1233/1234). Rastko od otcova dvora potají utekl ze Srbska na Svatou Horu Athonskou a stal se tam mnichem jakožto Sáva. Nemanja sám pak trůnu dobrovolně se vzdal a šel do kláštera jako mnich Symeon, nejprve do kláštera Studenici, který sám založil, později k synu svému Sávovi na Athos, kde zprvu přebývali v klášteře Vatopedském. Brzo založili tam, na místě starší od mořských loupežníků zničené mnišské osady, nový klášter Chilandar, v němž Nemanja zemřel r. 1200. Podařilo se mu v Nikáii vyjednat založení autokefální srbské pravoslavné církve a sám byl vysvěcen na prvního srbského arcibiskupa. Z funkce arcibiskupa měl dohled nad srbskémi státními záležitostmi. Dával přednost východní církvi před západní.

8 VELMAR-JANKOVIĆ, Svetlana: Vračar. Beograd: Prosveta, 1994, s. 46.

9 Petar Nikolajević Moler (1775-1816) býl malířem, proslulým tím, že vyzdobil kostel svatého Jiří v Topole. Moler se zúčastnil prvního (1804) a druhého (1815) srbského povstání. Byl popraven v Bělehradě ve Nebojšově věži. 
Podobně jako byly zobrazené osobnosti v knize o Dorćolu, také duch Petra Nikolajeviće, později pojmenovaného Moler (Malír) podle jeho povolání - malír ikon, chodí prostorem Bělehradu, ulicí nesoucí jeho jméno i místem, kde byl popraven, tedy v Dolním Městě kolem zchátralé Nebojšovy věže. Na rozdíl od př́íladů z románu Hodrové jeho duch nezasahuje do skutečnosti, je spíše v úloze pozorovatele všeho, co se kolem děje. Už na začátku svého vyprávění v próze Vračar Svetlana Velmarová-Jankovićová uvádí, „že smrt sloučila dva průběhy Molerova života, o kterých už staleti trvale šeptaji jeho dva stiny, a přece marně, protože je nikdo neslyš ‘“..$^{10}$

Město se pro Svetlanu Velmarovou-Jankovićovou stává prostorem kulturně-politických událostí, prostředím, které pamatuje a nese jména těch, kteří ho stavěli, bořili, vytvářeli či pojmenovali: Singidunum, Kopec, Alba Grecu, Sedmovrch, Bělehrad. Je to do̊m a hrobka. Pro Hodrovou je město souborem soukromých zkušeností, které zažila během dětství a adolescence prostoupených kolektivními, národními dějinami, jejichž němým svědkem byla stále Praha. V próze Trýznivé město spisovatelka líčí životní příběh svůj a svých blízkých, který organicky vkládá do příběhů lidí neznámých i proslulých, živých i mrtvých, skutečných i smyšlených literárních postav. Na jednom místě v knize Citlivé město uvádí, že kolektivní nevědomí města, s nímž komunikuje nevědomí obyvatel, si lze představit jako všeprostupující živel. Tento živel by mohl být nazván duchovním pólem nebo aurou. Aura města je jakousi všepamětí, s níž je lidské vědomí, či v tomto případě nevědomí, jemnými vlákny spjato. Duchovní charakteristiky města se skládají jednak z dispozic místa a také povahy všech staveb, jednak z životních příběhů, snů, myšlenek všech obyvatel a z kolektivních legend. ${ }^{11}$ Podle tohoto modelu vznikla její próza Město vidím, ve které Hodrová řadí obrazy toho, co „vidí“ ve vlastní paměti vztahující se k představám Prahy.

Ve své teoretické práci o městě Hodrová nejednou uvádí i postoje bělehradského architekta Bogdana Bogdanoviće (1922-2010), který rozlišuje dvě paralelní města - viditelné a neviditelné, mužské a ženské. V tomto duchu česká literátka pokračuje, že město, které se zjevuje ve snu nebo které člověk vnímá ve dne ve svém nitru v sobě slučuje obě města, přitom to intuitivní, nevědomé město prožité ve snu nebo věštbě je svojí povahou spíš jinové, a převažuje nad městem denním, rozumovým, svou povahou spíš jangovým. Nevědomí, kolektivní i osobní, je kolážové povahy. ${ }^{12}$ Přesto je pro její literární tvorbu zvláštní pojetí sebereflexivního a iniciačního románu, respektive románu zasvěcení, jak o tom píše Lubomír Machala; ${ }^{13}$ jedná se o druh hermeticko-gnostické prózy, kterou se zobrazuje ezoterická pout po rodném městě za sebepoznáním. To je právě koncept, podle kterého byla vybudována trilogie Trýznivé město obsahující romány - Podoboji, Kukly a Théta. Prvotina Hodrové je vyprávěná, jak o tom přemýšlí sama spisovatelka, podobně vesmíru v současné době, nazíraném jako nekonečná sít událostí ve vědomí, přičemž distance mezi vnímajícím a vnímaným je zrušena, představuje i město podobnou sít

10 VELMAR-JANKOVIĆ, Svetlana: Vračar. Beograd: Laguna, 2007, s. 7.

11 HODROVÁ, Daniela: Citlivé město. Praha: Akropolis, 2006, s. 357.

12 Tamtéž, s. 356.

13 MACHALA, Lubomír: Próza. In: HRUŠKA, Petr et al.: V souřadnicích volnosti. Praha: Academia, 2008, s. 289 . 
událostí ve vědomí a nevědomí a analogicky je zlikvidována hranice mezi městem a obyvatelem - město a jeho obyvatelé jsou jedním organismem - zvláštní Bytostí. ${ }^{14}$

V úvodu k anglickému překladu románu Daniely Hodrové Podoboji (1991, A Kingdom of Souls, 2015) obrací překladatelka Elena Sokolová pozornost na zvláštní postup Hodrové při budování narativu. Připomíná, že v už zmíněné monografii Citlivé město (2006) Hodrová vysvětluje způsob, kterým bychom měli rozumět současné próze založené na genderové povaze, přičemž používá známý koncept ze starobylé čínské filozofie o jinu a jangu (ženském a mužském principu), aby rozlišila dva základní typy textů: „text tkaninu nebo tkáň“ (jin text) ve vztahu k „textu-proudu nebo brázdě“ (jang text). Zatímco jang-text má převážně tendenci k homogennosti a linearitě, tkaný text ztělesňuje mnohorozměrnost a heterogennost. Tkaný text má povahu sítě nebo tkáně a obsahuje hodně copů a vypravěcích os, bez jasných začátků a konců; takový druh textu zároveň obsahuje širší kolektivní vědomí a nevědomí a je naplněn archetypálními a mytologicko-metaforickými souvislostmi a spojeními. ${ }^{15} \mathrm{Z}$ tohoto hlediska pak není ani divu, dozvíme-li se, že oblíbeným filozofem Daniely Hodrové je Carl Gustav Jung.

Hodrová navíc sděluje, že obyvatel v sobě město zrcadlí, ale zároveň svou náladou ovlivňuje rozpoložení města, jeho auru, která na něho zpětně působí, a že některá místa jsou více než jiná „branami“, jimiž lze vstoupit do aury města - do jiné, neviditelné Prahy. ${ }^{16}$ Tím pádem se o některých místech Hodrová často zmiňuje a věnuje jim významnou pozornost ve zmiňované trilogii, zvláště v Podobojí. Na př́klad se jedná o Hagibor, Žižkov, Olšany, Šibeničák (Šibeniční vrch), Staroměstské náměstí, Bílou Horu, ale také o legendární Blaník, Kutnou Horu a jiná místa. Ovšemže uvedená místa mají zvláštní význam pro dějiny města, protože se jedná o dějiště historických změn, revolucí či o popraviště nebo hřbitovy. S tím souvisí jedna z kapitol románu s názvem Revoluce, která se antropomorfním hlasem představuje čtenáři: „Jsem revoluce. Jsem revoluce na Hradě a jsem revoluce na Olšanech, jsem revoluce na Lobkovicově náměstí, revoluce v Kouřimské a jsem i docela malá revoluce v Zásmucké - to je úzká ulička, která vede kolmo do hřbitovni zdi [...] Jsem revoluce, živel očištujici a živel rozlišujicí, živel proměňujici a živel obracejici." "17

Ve stejném románu spisovatelka vysvětluje, že v každém prostoru jsou místa zlá a místa dobrá, místa zatracení a místa vyvolená. A kromě toho existují místa pomezní, místa dvojznačnosti a váhání mezi dobrem a zlem, na nichž nepozorovaně jedno přechází v druhé, obrací se ve svůj protiklad. Jsou to místa podobojí, co je pro jednoho místem dobrým, pro jiného místem zlým, a naopak. Kromě toho existuje těsný vztah mezi místem a bytostí, které se jmenuje genius loci. Místo v tuto bytost zvláštním způsobem přechází. ${ }^{18}$ Zmíněnou dvojakost je vidět i v případě postav, které jsou mrtvé a nějakým způsobem vlastně nejsou. Duše těchto postav, dávno zemřelých a popravených lidí, odmítají opustit svůj dům a neustále pokračují se všedními událostmi, jako by ještě žili,

14 HODROVÁ, Daniela: Citlivé město. Op. cit., s. 359-360.

15 SOKOL, Elena: Introduction. In: HODROVA, Daniela: A Kingdom of Souls. London: Jantar Publishing, 2015, s. p.

16 HODROVÁ, Daniela: Citlivé město. Op. cit., s. 359.

17 HODROVÁ, Daniela: Trýznivé město. Praha: Malvern, 2017, s. 34-36.

18 Tamtéž, s. 52. 
jako např. hrdinka Alice, jež neúnavně opakuje svoji chůzi ulicemi Prahy a navštěvuje rodinný dům naproti Olšanským hřbitovům. Právě v této souvislosti jsou místem, v němž se osudy mnoha významných osob českého veřejného života 19. a 20. století setkávají, pražské Olšanské hřbitovy. Na tomto místě dochází k svéráznému anachronismu, protože na hřbitově byly pohřbeny osobnosti z různých období a na této půdě se v románu Hodrové setkávají a pojednávají o své vlasti. Hodrová poznamenává, že se Olšany z vinohradů staly hřbitovem za velkého moru roku 1680, když vznikly hřbitovy staroměstský, novoměstský a židovský. Její mrtví hrdinové cítí neustálý stesk po svém bývalém životě, ale zároveň je to jenom asociace života, který kdysi existoval - život v demokracii první republiky. Proces obrození pokračuje na Olšanských hřbitovech a nezastaví ho temná tušení pana Turka. Ilustrace „pražského jara“ se v románu Podoboji vztahuje na celou řadu jmen z českých kulturních dějin z počátku 19. století a období národního obrození, když Hodrová uvádí tytéž osobnosti v textu románu jako své postavy. Toto je patrné zvlášt při setkání pana Klečky s panem Šafaříkem a hned potom v neúnavném hledání pana Palackého (za obrození přezdívaného Otec národa). Téma pražského jara se prolíná s tématem národního obrození, narážeje přitom na kulturně-historickou regeneraci jednoho národa. A s tím souvisí celá řada známých jmen - Kollár, Havlíček Borovský, Sabina, Šafařík, Palacký a jiní. ${ }^{19}$

Na straně druhé neklidný duch sebevražedkyně Alice neustále běhá po cestě mezi Šibeničním vrchem a Žižkovem ke kostelu svatého Rocha, hledaje ztracenou lásku Pavla Santnera. Tato místa jsou velmi zajímavá, protože jde o veřejná popraviště, kde se popravy konaly až do roku 1866 (kdy byla provedena poslední poprava na Karlově náměstí). Popraviště existovala v Praze na několika místech už od středověku a o některých z nich se Hodrová zmiňuje v románu. Šibenice stály na Koňském trhu (Václavském náměstí), Staroměstském rynku, na Petříně; a ze Staroměstského rynku byla pak šibenice přenesena na tehdy pustý vltavský břeh, na místo, kterému se říkalo, a dodnes říká, Na rejdišti. ${ }^{20}$

Abychom těmto místům lépe rozuměli, Elen Sokolová podtrhuje, že velmi důležité jsou historické a kulturní narážky Hodrové, které pomohou porozumět textu románu. ${ }^{21}$ Na jedné straně jde o volnou alegorii, kterou se představují české země po dlouhých staletích strávených v rámci habsburské monarchie a které se po založení první republiky měly rozvíjet ve „svobodě“. Na straně druhé se větší část narativu odehrává od doby druhé světové války až do osmdesátých let 20. století. Ta léta zahrnují nacistickou okupaci, květnové povstání v Praze, vyhnání Němců, komunistický převrat v únoru roku 1948, následně pražské jaro, za kterým následovala invaze vojsk Varšavské smlouvy a v důsledku toho násilná politická normalizace. Jsou to zkrátka dějiny Česka 20. století, jež nelze

19 Uváděním jmen známých osobnosti 19. století na tomto místě pozorujeme jistou analogii v narativu obě spisovatelky v případě zobrazení rodného města. Není náhodou proč právě vybraly toto století, když se jedná o základy osvícenství, kulturní a politickou činnosti, což konečně přivedlo k založení suverenity. Vzhledem k tomu posuzujeme, že se individuální lidské osudy odrážejí na veškerý úděl národní.

20 Podrobnosti o těchto údajích se autorka př́spěvku dozvěděla na internetové stránce: http://www.hrdelnipravo.cz/popraviste/praha.html.

21 SOKOL, Elena: Introduction. In: HODROVA, Daniela: A Kingdom of Souls. London: Jantar Publishing, 2015, s. p. 
posuzovat, a jimž nelze porozumět bez znalosti středověkých událostí. Ostatně jen s nimi lze také vysvělit název románu Podobojí. V tomto kontextu se v románu Hodrové následně popisuje období protireformace a pronásledování nekatolíků po bitvě na Bíle Hoře, období národního obrození a první republiky. V závěrečném dílu trilogie, románu Théta, spisovatelka napovídá, že píše o románu, ale také, že píše romány: „Je to trilogie. - Tedy trilogie... O čem? - O Praze. [...] - O jaké Praze? - O Praze současné, ale i o té minulé. Děje různých dob se prostupuji - od staroměstské exekuce až po rok osmašedesátý..."22

Je tedy otázkou, nakolik se Hodrová personální vypravěčskou situací (podle Stanzla) vůbec obrací na „srozuměného“ čtenáře s ohledem, že její narativ připomíná somnambulní noření do vlastního vědomí a nevědomí Prahy a celého českého národa. Životy zobrazených postav v Podoboji se podobají alegorii, symbolu nebo ideji. To nejsou žijící osobnosti - to jsou jenom vzpomínky, památky, kulturní vztahy a politické události. Celý román Hodrové lze číst jako alegorii města, které sní o svých obyvatelích; je to jediný způsob, kterým se dají vysvětlit jevy živých a mrtvých koexistujících současně na jednom místě. Název románu o tom zřejmě svědčí, Hodrová jím chtěla ukázat, že Praha (a vůbec česká země) vsála mnoho krve a přijala hodně událostí a ted' požehnává svůj národ touto symbolickou a doslovnou obětí.

Prostupováním životů živých a mrtvých je zřejmé, že Hodrová vybudovala nemožný svět na látce skutečného prostoru města, nebot její mrtvé postavy odmítají opustit svůj dům v bytě naproti Olšanským hřbitovům. Lubomír Doležel její postup vysvětluje jako „logický nemožný fikčni svět, protože obsahuje logické protiklady“. O něco dál pokračuje slovy, že „hlavnim prostředkem konstrukce logicky nemožného fikčního světa v Podoboji je zrušeni protikladu mezi vlastnostmi ,být živý a , nebýt živy“ " . ${ }^{23} \mathrm{Na}$ žádném místě nenalezneme vysvětlení přítomnosti mrtvých kromě jejich vlastních hlasů, kterým oznamují: „Jsme dušičky. Vznášíme se povětřim. Žijeme v ohni $i$ ve vodě, kráčime po zemi. Ze všech živlů dáváme však prednost vzduchu, živlu nejabstraktnějšimu, Anaximenovu apeiron aer a zároveň živlu nejtěsněji spjatému s životem, s dechem. Jsme ztělesnèný dech, náš vdech a výdech rytmují běh vesmíru. V protikladu život - smrt nalézáme se právě na hranici, na hranici, ach, príliš vágní. Jsme zpola božské a zpola lidské a tímto suým založením se podobáme hrdinům mýtü, sestupujicím na zem osvitit nevědomé lidstvo. “24

Postavy jsou živé nebo mrtvé, beránci připravení na obět jako Jan Paskal (symbolického jména Paškál z latinského paschalis a řeckého pascha, a to původně z hebrejského pesah), rodina Davidovičova, pan Klečka s panem Turkem oproti lumpům a darebákům jakýchkoliv jmen (Moždíř a Divočák, Mortier a Sanglier, Roháček a Boháček, Brůna a Rubeš, Platon Lvovič Glinka a Kosta Suchoručkov) ${ }^{25}$. Postavou doktora Kožíška v románu

22 HODROVÁ, Daniela: Théta. Praha: Československý spisovatel, 1991, s. 193.

23 DOLEŽEL, Lubomír: Heterocosmica II. Praha: Karolinum, 2014, s. 95.

24 HODROVÁ, Daniela: Trýznivé mèsto. Op. cit., s. 46.

25 Vzhledem k užití nezvyklých (podivných) jmen jednotlivých postav a jejich objevení v textu románů (např. v Podoboji), Jana Bartůňková a Alena Zachová všimly, že lze hovořít o zvláštním způsobu zdvojování (BARTƯŇKOVÁ, Jana; ZACHOVÁ, Alena: Problém dvojnictví v trilogii Daniely Hodrové. Česká literatura 42, 1994, č. 5, s. 527). Takovou donekonečna se kopírující dvojicí jsou - Moždír a Divočák, Mortier a Sanglier, Roháček a Boháček, a ostatní. Když jde o určení funkci postav je také pozorovat motiv prolnutí člověka s různými předměty a zvírraty, což upozorňuje na neustálou změnu psychického nebo fyzického stavu a trvalou metamorfózu lidí a věcí (příkladem toho je právě román Kukly). Tímto pochybem se umožňuje 
Podoboji Hodrová začala s rozpracováním motivu kůže s mnohonásobným významem. Kůže především odkazuje na druh oděvu, šatů, na něco, pod čímž se skrývá skutečná povaha člověka (vlk v rouše beránčím), ale také odkazuje k možnosti transformace lidí a změně jejich charakterů svlékáním kůže. Motivu metamorfózy lidí a změny jejich povahy se Hodrová věnuje v dalším románu trilogie s názvem - Kukly, v němž pomocí postavy Sofie Syslové představuje její vnitřní metamorfózu, která se zároveň odehrává ve městě samém. O tom čteme, když spisovatelka vypráví o její lásce - k básníkovi: „A básnik Hynek Machovec, který právě zažil proměnu v motýla ze svého dětstvi, docházi k poznáni, jak je vratká, a přitom jak plynulá hranice mezi tím, co je zatím zvenči a od nás odděleno, a tím co už je uvnitr̆ a co s námi splynulo, neboli mezi tím, co dosud vnímáme jako cizorodý predmèt, který se nám přisál k tělu, a tím, v co se tělo proměnilo“. ${ }^{26}$ Tímto textem Hodrová vysvětluje, že nejen lidé, ale také místa jsou zakuklená, ale nikdo dobře neví, kdy nastane okamžik jejich svlékání, kolika proměnami budou muset projít. Jednoho dne se jejich povrch napne a místa puknou. A potom kukla odpadne a pod ní se objeví to skryté, pravé místo, to, které bylo a zas bude. Pan Turek ale vysvětluje, že pod kuklou někdy bývá zase jen kukla a svlékání může pokračovat. A kdoví kolik let dělí takové jedno svlékání od druhého. ${ }^{27}$ Jak zde čteme, pan Turek se z Podoboji přesunul do Kukel, protože se příběhy třech románů navzájem prolínají a doplňují.

Ve svém teoretickém díle Hodrová sděluje, že město absorbuje myšlenkovou energii lidskou, přejímá určité lidské charakteristiky, tak jako je přejímá dům nebo věci, jichž se člověk dotýká, a tedy město do jisté míry skutečně „ožívá“, je živé. V románu Kukly se dovídáme, že některá místa se přece musejí obcházet v kruhu, aby vydala své tajemství (proto se tady jedná o cyklické vyprávění), jiná napříč, křížem krážem. A na některá se musí vystupovat a zase z nich sestupovat. U mrtvých je tomu ovšem jinak, i když oni mohou místa obcházet i způsobovat jejich proměnu. Nejčastěji se to daří těm, kteří se ještě zcela neodpoutali od světa živých a touží se do něho vrátit. Ale někteří mrtví prohlédají všemi vrstvami prostoru a času. Stačí, aby se rozpomněli, a místo, na které upírají zrak, zprůsvitní a začne se proměňovat. ${ }^{28}$

Po Podoboji a Kuklách Hodrová, jak o tom sama píše, měla v úmyslu napsat román, který by reflektoval sám sebe a celý byl pojat antiiluzivně. Proto se na mnoha místech pokusila o text takřka autobiografický, nebot’ se v něm objevily postavy i předměty z předchozích dvou románů, a intertextuálně i postavy z cizích románů. O svém literárním postupu v románu Théta přemýšlí slovy: „Vypadá to tak, že když jsem vstoupila do trýznivého města, musím znovu procházet místy, o nichž jsem už psala, a potkávat se tam s postavami, které jimi prošly přede mnou. Na konci bude mít Olšanská komedie nebo Trýznivé město (ty dva názvy pro trilogii mě napadaji) možná stovky postav. “29

dynamizace narativního časoprostoru a ukazuje se na archetypální základy, kterými se tvaruje nejenom románová skladba nybrž také postavy hermetického textu Hodrové. 
Právě v textu románu posuzuje, že se jedná o román rodinný a rodový, protože se rozhodla psát o svém otci, čímž se román stal textem o hledání otce. Tím pádem vlastní sestup do minulosti popisuje, jako by to byl sestup do noci a „k předkům, na nichž nás fascinuje a zneklidňuje podoba s námi“ ${ }^{30}$ Jako i v předchozích románech, stejně tak tady rozpadající se rodina zvětšuje zármutek hlavní postavě Elišce Beránkové, se kterou se autorka ztotožňuje. Pro ni se smrt obou rodičů stává nesnesitelnou a nepřekonatelnou; jejich smrt se podobá smrti vlasti, volnosti a identity národní. Je to román o trýznivém městě a o Elišce Beránkové, která hledá mrtvého otce. Její sestup k otci je zároveň sestupem do jejího dětství a do vlastního nebytí.

V románu Lagum (Žalář) Svetlana Velmarová-Jankovićová fiktivním povídáním oživuje reminiscenci na svého otce za kolaborantské vlády v Srbsku během druhé světové války. Hodrová otce ztratila v zápasu s nemocí, Velmarová-Jankovićová v zápasu s opozičními ideologiemi během války. Vyprávěním románu Lagum spisovatelka na jedné straně buduje fiktivní pověst, zatímco se na straně druhé dotýká bolavých míst autobiografických vzpomínek. Tímto Lagum, jenž je vyprávěn v ich-formě, představuje reminiscentní ráz intimních událostí autorky textu prostoupených kolektivními dějinami, což jsme mohli vidět na př́kladu románů Hodrové. Čas vyprávění je přemístěn a nemá chronologický sled; vypravěčka hovoří o několika „ted““ sjednocených v jednu emoci, kterou neustále cítí a prožívá v rodném městě. Čas jejích záznamů je rok 1984, zatímco se její jiná „ted”“ dějí v letech před druhou světovou válkou, během ní a po ní. Soukromou zpovědí Velmarová-Jankovićová podává svědectví o převratných a turbulentních změnách v zemi, ve které se narodila a kde strávila celý svůj život. Je to současně svědectví i o různých transformacích města a lidí, o ztroskotání měštanské společnosti a o změnách nejenom ideologie, nýbrž společenské třídy, o lžích, pokrytectvích a okrádání občanů o jejich osobní majetek.

Úpadek bývalých časů, prvorepublikových (v případě českém) a Království Jugoslávie, obě spisovatelky šikovně zobrazily fenomenologickou proměnou plnosti v nicotu. Kdysi plné regály exotických čajů a kávy, anglických mýdel, lískových ořechů, medu, jižního ovoce a vína $\mathrm{v}$ obchodech najednou zůstaly př́̌šerně prázdné (dlouho po válce), jak popisuje Velmarová-Jankovićová. Byty (alespoň ty v budovách, které nezničilo německé a americké bombardování v letech 1941 a 1944) byly vybydlené, bez veškerého nábytku a cenností, nebo jednoduše nejdřív byly vylidněny a potom zabydleny novými osvoboditeli. O tom svědčí i následující slova: „Někde v pohybu času se ztratil jakýkoli pořádek a vkus, jako bych opakovala větu své babičky, jež se současně ztratila v pohybu času, zmizela v nějaké zatáčce, moje babička a jeji Velký řád s Velkým smyslem, všechno bylo utopeno v prázdných prostorech, všechno kromě tohoto ted', které je tady puls úžasu, před kterým jsem vztyčená, nehybná, vyprázdněná, zdánlivě připravena na ránu."31

Úpadek jedné doby bylo vidět také na př́kladu nábytku chippendale, který se z půvabného, sentimentálního předmětu stal předmětem závisti, kořisti, moru; od jemného, ušlechtilého vztahu jeho původních majitelů (měštanské rodiny Pavlovičových)

30 Tamtéž, s. 52.

31 VELMAR-JANKOVIĆ, Svetlana: Lagum. Beograd: Dereta, 2013, s. 18. 
k posedlosti těch, kteří si ho sílou přivlastnili (Petar Zec, důstojník a člen Komunistické strany). Úpadek dobrých časů se u Hodrové symbolicky představuje postavou Laňky (Podoboji), který hledá a sbírá tenisové míčky. Hermeticky řečeno, Hodrová nejdřív úvodem líčí padesátá léta 20. století a pomocí osudu člověka jménem Laňka porovnává nově nastalé časy se zlatými časy první republiky. Motiv tenisových kurtů navozuje asociaci ušlechtilé a spokojené společnosti oproti časům, které následovaly hned po jejich zániku, a po dlouhou dobu byly rozpoznatelné podle červené barvy, nebo podle postav, jako je správce Šípek. „Nenajde-li Laňka své mičky, “ říká Hodrová, „nevráti se nikdy ten blahý čas. Laňka v bilém nebude hagiborským sběračem mičků - nebot svoboda mladá, v červený květ rozkvetlá, naloži celou kupu Laňkových mičkủ, a odveze proni republiku“. ${ }^{32}$

Styčné body mezi dvěma spisovatelkami lze spatřit v jejich percepci národních dějin, které prostupují jejich beletristické dílo o rodném městě (Praze, Bělehradě), ve středu pozornosti obou autorek také stojí budovy, památníky a různé kulturní památky jednoho města. Praha s Bělehradem jsou - a proto Hodrová cituje Danta - Città dolente. $\mathrm{Z}$ těchto důvodů se u české literátky jedná o zvláštní druh textu - bující tkáně, text se někdy bolavě rozrůstá $\mathrm{v}$ elegii (žalozpěv) nad městěm. $\mathrm{V}$ případě rodin (v románech Lagum a Kukly) nalézáme souvislost mezi některými z postav, což se týká uměleckých předmětů nebo obrazů doprovázejících jejich soukromé životy (v Lagumu paní Pavlovičová chová sentimentální vztah k nábytku chippendale a obrazům Savy Šumanoviče; v Kuklách se mimo jiné objevuje celá řada důležitých předmětů rodiny Syslů - polštár̆, harfa, otáčecí křeslo, věšák Ka a láska pana Sysla k secesi, obrazům Pirnera a Preissiga). Naratologickou a sémantickou komplexnost románů Daniely Hodrové nelze jednoduše představit, jenom ji vybranými tématy můžeme postupně vysvětlovat a luštit. Tuto vypravěčskou složitost ve vyprávěcím postupu Svetlany Velmarové-Jankovićové nenalézáme, ačkoliv pestrost a hojnost jejího výrazu není o nic menší než u české spisovatelky. Třebaže mají rozličnou poetiku, individuálním zaměřením se podílejí na zobrazování rodného města specifickým modelem, obrácením se k dějinám - národním a subjektivním. Autorka tohoto př́spěvku zjištuje, že stojí za to přeložit díla obou spisovatelek do jazyka té druhé, aby se čeští i srbští čtenáři seznámili s vynikající literární tvorbou dvou důležitých autorek 20. i 21. století, protože jde o díla v současné české a srbské literatuře zcela mimořádná.

\section{Prameny}

HODROVÁ, Daniela: Kukly. Praha: Práce, 1991. 278 s.

HODROVÁ, Daniela: Théta. Praha: Československý spisovatel, 1992. 200 s.

HODROVÁ, Daniela: Citlivé město. Praha: Akropolis, 2006. $404 \mathrm{~s}$.

HODROVÁ, Daniela: Trýznivé město. Praha: Malvern, 2017. 598 s.

VELMAR-JANKOVIĆ, Svetlana: Dorćol. Beograd: Beogradski izdavačko-grafički zavod, 1986. 213 s. VELMAR-JANKOVIĆ, Svetlana: Vračar. Beograd: Prosveta, 1994. 96 s.

32 HODROVÁ, Daniela: Trýznivé město. Op. cit., s. 54. 
VELMAR-JANKOVIĆ, Svetlana: Vračar. Beograd: Srpska književna zadruga, 2007. 152 s.

VELMAR-JANKOVIĆ, Svetlana: Lagum. Beograd: Dereta, 2013. 261 s.

\section{Literatura}

BARTU゚ŇKOVÁ, Jana - ZACHOVÁ, Alena: Problém dvojnictví v trilogii Daniely Hodrové. Česká literatura 42,1994 , č. 5 , s. 522-532.

DOLEŽEL, Lubomír: Heterocosmica II. Praha: Karolinum, 2014.

GORDIĆ-PETKOVIĆ, Vladislava: Urbana topografija u americkoj i srpskoj prozi : egzil i heterotopija. In: ČUBROVIĆ, B. (ed.): Grad u jeziku, književnosti i kulturi. Beograd, Philologia, 2005, s. 67-74.

JEREMIĆ, Zoran: Istorija i pripovedanje. In: PANTIĆ, M. (ed.): Bezdane svetlosti. O književnom delu Svetlane Velmar-Janković. Beograd: Biblioteka grada Beograda, 2012, s. 5-47.

MACHALA, Lubomír: Próza. In: HRUŠKA, Petr et al.: V souřadnicích volnosti. Praha: Academia, 2008, s. 275-311.

SOKOL, Elena: Introduction. In: HODROVA, Daniela: A Kingdom of Souls. London: Jantar Publishing, 2015.

doc. dr Ivana Kočevski

Filološki fakultet, Univerziteta u Beogradu

Studentski trg 3, 11000 Beograd, Srbsko

ivana.kocevski@fil.bg.ac.rs 
